\title{
Chancery Procedure and the Seventh Amendment: Jury Trial of Issues in Equity Cases Before 1791
}

\author{
Harold Chesnin ${ }^{\dagger}$ and Geoffrey C. Hazard, Jr. $\ddagger$
}

The jury is like rock music. Classical theory frowns; the masses applaud. And in a democracy the felt need of the masses has a claim upon the law. ${ }^{1}$

There is some evidence that courts of equity in the eighteenth century and before, and in the early part of the nineteenth century, relied on procedures involving jury trial to determine disputed questions of fact. Because the evidence is modest it suggests rather than demonstrates the validity of the inferences that may be drawn from it. At the same time these inferences may be significant in assessing the constitutional position of jury trial in this country. This article seeks to contribute to that assessment and to encourage further research.

Broadly, the evidence suggests that at the time of the adoption in 1791 of the Seventh Amendment guarantee of jury trial "in Suits at common law," the practice in the English Court of Chancery was in transition. The court was moving from a rule that disputed fact issues were generally, if not invariably, submitted to juries to one that made such submissions discretionary. The character of this transformation may be inferred from the language of cases decided at different points before and after 1791. In Webb v. Claverdon, ${ }^{2}$ decided in 1742, the court said:

\footnotetext{
t Member of the New York Bar.

$\ddagger$ Professor of Law, Yale University. The research on which this article is based was done chiefly by Mr. Chesnin under the supervision of Mr. Hazard while both were at the University of Chicago as, respectively, student and member of the faculty. Mr. Chesnin's research in original records in the Public Record Office in London and in the Huntington Library in Pasadena, California, was made possible by financial support from the American Bar Foundation, which also sponsored the project as a whole. The American Bar Foundation makes no endorsement of the conclusions and opinions expressed, which are those of the authors. The authors express thanks to the Foundation for its assistance and also to Stanley N. Katz of the University of Chicago, William J. Jones of the University of Alberta, and Barbara Black and Robert Cover of Yale University for critical suggestions.

1. 5 Moore's Federal Practice T 38.02[1], at 15 (2d ed. 1971).

2. 2 Atk. 424, 26 Eng. Rep. 656 (1742). But cf. Bennet v. Vade, 2 Atk. 324, 26 Eng. Rep. 597 (1741), where the Court of Chancery apparently undertook itself to determine the facts in the case of an allegedly insane testator.
} 
This court will not determine a fraud, in procuring a will, without directing a trial at law ....

The report in Bates $v$. Graves, ${ }^{3}$ decided in 1793, was:

When the cause came before Lord Thurlow, his opinion was strongly against the validity of these instruments; but it was insisted, that the Court could not set aside a will without directing an issue [to be tried before a jury]. The Lord Chancellor finally acceded to that opinion.

In Kemp v. Pryor ${ }^{4}$ in 1802, counsel argued:

The fraud imputed [in delivering goods not conforming to the terms of a sales contract] is cognizable at law; and must be found by a jury. It is not a proper subject of inquiry before the Master. There may be contradictory evidence.

In 1803, the court said in Warden of St. Paul's $v$. Morris: $:^{5}$

This Court has a right, to be exercised very tenderly and sparingly, of deciding without any issue [being framed for trial to a jury].

No earlier, apparently, than Hampson $v$. Hampson in 1804 did the court of equity refer an issue to a jury as a matter of discretion rather than routine: ${ }^{6}$

$[\mathrm{I}] \mathrm{t}$ is a competent Exercise of the Authority and Duty of the Court in every Case ... to determine according to its Discretion, whether it does, or not, want [the] Assistance [of a Jury].

This line of reports indicates that the rule that a court of equity may decide fact issues itself was not firmly established in England until some time after 1800, at least a decade after the effective date of the Seventh Amendment. The English precedents indicate that in 1791 the Court of Chancery did not usually exercise authority to resolve contested issues of fact and seemingly did not regard itself as competent to do so.

3. 2 Ves. Jr. 287,30 Eng. Rep. 637 (I793).

4. 7 Ves. Jr. 237, 32 Eng. Rep. 96 (1802).

5. 9 Ves. Jr. 155, 168, 32 Eng. Rep. 561, 566 (1802). See also Pemberton v. Pemberton, 11 Ves. Jr. 50, 32 Eng. Rep. 1006 (1805); O'Conner v. Cook, 6 Ves. Jr. 665, 31 Eng. Rep. 1247 (1802).

6. 3 Ves. \& Bea. $41,42,35$ Eng. Rep. 395 (1804). 


\section{Procedures for Referral from Equity to Common Law}

During the period from the early seventeenth to the early nineteenth centuries, the equity side of Chancery ${ }^{7}$ often relied upon the courts of common law for the determination of difficult questions of law and fact. Chancery employed three procedures to bring issues before the common law courts: (1) the case stated for determination by the justices of the courts of common law; (2) the action at law; and (3) the feigned issue. The use of the case stated and the action at law by the High Court of Chancery were already well established at the beginning of the seventeenth century. ${ }^{8}$ The use of the feigned issue appears to be a later development. ${ }^{9}$ In the course of time these procedures evolved into a set of relatively fixed and formalized rules of practice, capable of standardized application under fairly well defined circumstances.

\section{A. The Case Stated Procedure}

The case stated for determination by the justices of the common law courts was employed as a means of obtaining a legal opinion on a question of law:

If a question of mere law arises in the course of a cause, as whether by the words of a will an estate for life or in tail is created, or whether a future interest devised by a testator shall operate as a reminder or an executory devise, it is the practice of this court to refer it to the opinion of the judges of the court of king's bench or common pleas, upon a case stated for that purpose ....10

Upon determining that a case stated should be referred to the judges of a common law court, the Lord Chancellor formulated a recital of the material facts in the case, which were to be taken by the common law court as admitted, and certified the point of law that was to be decided. Before the case stated was transferred to the common law court for decision, the matter was first referred to a Master of the Court in order to provide the parties an opportunity to settle any disagreements about the facts to be admitted. ${ }^{11}$

7. In discussing equity in England, we will concentrate on the High Court of Chancery, with only minor reference to such other equity courts as Exchequer.

8. See W. Jones, The Elizabethan Court of Chancery 474-85 (1967).

9. See pp. 1005-06 infra.

10. 3 W. Blackstone, Commentaries on the LAW of ENGland $452-53$ (5th ed. 1773).

11. See, e.g., Parsons v. Parsons, Public Record Office Chancery Decree and Order Books C33/495, at 711a-11b (1796). [Hereinafter, all Public Record Office documents are cited as PRO.] The order in Parsons read:

Whereupon and upon debate of the matter and hearing the probate of the will of William Colc dated the 7 th of July 1789 read and what was alledged by 
The decision of the judges of the common law court was returned to Chancery in the form of a Certificate..$^{12}$ When it received the Certificate, the court either ordered the case to final disposition ${ }^{13}$ or, if dissatisfied, ordered the case sent back to the same or another common law court for a de novo determination of the question of law. ${ }^{14}$ In any event, when the Lord Chancellor received a satisfactory Certificate the case was set for final disposition.

the counsel on both sides, His Honor doth order that a case be made for the opinion of the Judges of his Majesty's Court of King's Bench stating that William Cole by his will dated the 7 th day of July 1789 gave a leasehold estate to his executors in trust to pay the rents and profits thereof to Isabella Henwood until three months after the death of his wife Mary Cole. And in case the said Isabella Henwood should be then living and have attained her age of 21 years, then he gave the said leasehold estate together with all arrears of rents and profits that were due thereon to the said Isabella Henwood to and for her own use. But in case the said Isabella Henwood should happen to die under 21 and unmarried before the end of three months next after the decease of his said wife Mary Cole, then and in such case, he thereby directed that the said leasehold should sink into and become part of the residue of his personal estate. And in case the said Isabella Henwood should survive his wife Mary Cole and at the time that she should become intitled to the possession of the said leasehold estate she should be married, then the said testators mind and will was and he did further direct that his executors and trustees and the survivors or survivor of them should assign the said leasehold estate unto such person or persons and unto such ends, intents, and purposes as the said Isabella Henwood should notwithstanding her coverture by deed or deeds in writing to be executed in the presence of two witnesses direct or appoint .... It was the said testators will and mind ... should assign over the said leasehold estate ... among all and every the child and children of the said Isabella Henwood lawfully begotten who should be living at the time of her decease.... That the said Isabella Henwood attained the age of 21 and afterwards married the defendant Robert Parsons and died leaving issue, the plaintiff George Parsons the infant. That the said Mary Cole the wife of the said testator is still living. And it is Ordered that the question thereupon be whether the plaintiff George Parsons or the defendant Robert Parsons the father as administrator of the said Isabella his late wife take any and what interest in the said leasehold estate or whether upon the death of the said Isabella the said leasehold estate was undisposed of and fell into the residue of the estate of the said testator William Cole. And it is further Ordered that it be referred to Mr. Pepys, one of the Masters of this Court to settle the Case in case the parties differ about the same and the Judges of the Court of King's Bench are to bc attended with the said Case. And His Honor doth reserve the consideration of all further directions until after the judges of the Court of King's Bench shall have made their Certificate and any of the parties are to be at Liberty to apply to this Court as there shall be occasion.

See also Horton v. Whitaker, PRO C33/465, part II, at 525a-26a (1786), where the Lord Chancellor merely formulated the question of law, leaving the tasks of drafting the admitted facts and reconciling disputes concerning them to the Master.

12. See Parsons v. Parsons, PRO C33/495, at 711b.

13. See Horton v. Whitaker, PRO C33/465, part II, at $730 \mathrm{a}-30 \mathrm{~b}$ (1786).

14. H. Grant, Practice of the High Court of Chancery 278 (4th ed. 1839). The frequency of such de novo referral is unclear. Professor Jones, in his study of Elizabethan Chancery practice, remarks that "there was nothing to compel a Lord Chancellor to accept the opinion of referees (judges) .... In practice, however, the court virtually never quarrelled with a certificate from referees. Had it done so, it would have destroyed the usefulness of this most valuable method of proceeding." $W$. JonEs, supra note 8 , at 482 . The familiarity with the practice of de novo referrals expressed in Grant in 1839 may suggest that, as the Lord Chancellor acquired greater judicial power, he interposed his disapproval of the first common law court decision with greater frequency-a phenomenon that would parallel the procedural development of the feigned issue discussed below. See W. BoHun, Cursus CancellariaE 21 (1715). 


\section{B. The Action at Law}

The second procedure for referral from equity to law was the more familiar action at law. This was used as a means of obtaining a common law determination of the legal rights of the parties with the aid of a jury. "The Court will sometimes also, on the hearing of the cause direct the bill to be retained for a certain time, giving the party whose interests are disputed liberty to bring his action for the purpose of ascertaining his rights at law ...."15

If, after hearing the cause in the High Court of Chancery, the Lord Chancellor determined that an action at law should be commenced, he entered an order "that the plaintiff's bill be retained for twelve months and that the plaintiff be at liberty in the meantime to bring an Ejectment and proceed to trial therein for the recovery of the premises in question."16 All parties were then required to produce all documentary evidence within their possession before the Master of the Court to allow any party to "inspect the same and to take copy therefor of such parts thereof as they shall think fit at their expense ...." The court further ordered that "such of the said deeds and writings as either side shall give notice of are to be produced at the said trial ...."17 Having insured that all relevant documents would be introduced in evidence before the common law court in the action at law, the Court of Chancery prepared the way for the final disposition of the equity suit. ${ }^{18}$

After the action at law had been tried, the parties returned to Chancery for the consideration of the equity reserved. The scope of the relief that could be granted upon the return of the action at law was limited in two ways. First, Chancery was unable to grant a greater relief than that given in the common law court. Furthermore, if one or both of the parties considered either the common law court's proceedings or verdict erroneous, the motion for a new trial could be made and granted only in the court of law where the trial had taken place. ${ }^{19}$ The Court of Chancery therefore could "look only at the final result,

15. G. Goldsmith, The Doctrine and Practice of Equity or a Concise Outline of the Proceedings in the High Court of Chancery 367-68 (4th ed. 1849). See W. JoNEs, supra note 8 , at 475-81.

16. Sands v. Sands, PRO C33/388, part II, at 573a-74a (1747). At times the order, while having the same legal effect, was couched in more general terms. In Moone v. Collingwood, C33/394, part I, at 60-61 (1749), the Court of Chancery retained the bill in equity for 12 months and ordered "that the plaintiff be in the meantime at liberty to bring such action at law for the demands mentioned in his bill as he shall be advised and proceed to trial thereon with the said twelve months . . .

17. Sands v. Sands, PRO C33/388, part II, at 573a-74a (1747). See also Moone v. Collingwood, C33/394 (1749).

18. Sands v. Sands, PRO C33/388. part II, at 573a-74a (1747).

19. H. GRANT, supra note 14 , at 277. 
and not at any of the proceedings at law" 20 to determine the equity to be decreed.

The case of Sands $v$. Sands ${ }^{21}$ illustrates the opportunities for procedural maneuvering and multiple retrials open to the parties in an action at law by the combination of Chancery's control over the final judgment and its lack of control over the proceedings in the common law court. After hearing the cause in Sands in May 1747, the Lord Chancellor ordered "that the plaintiff might bring an ejectment to recover the possession of the premises in question" and reserved further equity consideration pending the decision in the common law court. The plaintiff brought the ejectment action at the summer assizes for the County of Kent, but received an unfavorable verdict. The plaintiff received permission from the common law court to bring a second ejectment action and petitioned the Court of Chancery to retain the bill in equity for another 12 month period. ${ }^{22}$ After the Court of Chancery granted the motion the plaintiff brought the second ejectment suit at the next summer assizes for the County of Kent and received a favorable verdict.

At this point the defendant received permission from the common law court to bring an ejectment action in a second retrial, but the plaintiff set the case down for a hearing on the equity reserved at a time prior to the scheduled second retrial. ${ }^{23}$ The Lord Chancellor, however, ordered the hearing on the equity reserved adjourned, enabling the defendant to pursue the retrial granted by the common law court. The Chancellor conditioned his order upon the payment, by the defendant, of the costs of the last ejectment trial..24

Referral from Chancery to the common law courts by the action at law procedure seems to have been interchangeable with the feigned issue procedure. Chancery, particularly in cases involving contested inheritances, could rely upon the common law courts to decide the legal rights of the parties by an action at law. This practice, of course, would require the common law court to determine any disputed issues of fact before proceeding to render judgment on the parties' legal rights. Al-

20. G. GoLDSMITH, supra note 15 , at $367-68$.

21. PRO C33/394, part II, at 403b (1750).

22. Sands v. Sands, PRO C33/392, part II, at 449a (1749).

23. Sands v. Sands, PRO C33/394, part I, at 350 (1750).

24. PRO C33/394, part II, at 403b. The Chancellor stated:

In default of the defendant's paying unto the plaintiffs the cost of the last ejectment within the time before mentioned (ten days), it is further ordered that the defendant's proceeding in the said ejectment... . be stayed and the cause come on to be heard on the equity reserved ....

Conditioning the order on payment of costs by the defendant might be an indication of an attempt by the Lord Chancellor to limit the number of retrials. 
ternatively, Chancery could have the contested issues of fact tried in the common law courts by a feigned issue and reserve the judgment of the parties' legal rights for itself. Lord Chancellor Thurlow, in Countess of Strathmore $v$. Bowes, ${ }^{25}$ confirmed the availability and interchangeability of the two procedures. In determining the validity of a revocation of a conveyance made before marriage, Lord Chancellor Thurlow states, "It was a question of fact whether the revocation was obtained by duress, which might be tried in an ejectment or upon an issue."26

\section{The Feigned Issue Procedure}

The third referral procedure, the feigned issue, consisted of a trial by jury in a court of common law of questions of fact in dispute in a court of equity. The form of the feigned issue was a discourse between the parties concerning the disputed fact. A wager was made concerning the issue in controversy which was to be determined by a jury in a court of common law. ${ }^{27}$

The origin of the feigned issue and the reasons for its development are uncertain. It seems clear that by the Restoration period the procedure was used regularly. Lord Chancellor Nottingham discussed it in language suggesting that it was a common part of the practice of the Restoration Court of Chancery: "The multiplying of trials in feigned actions upon feigned issues is likewise an abuse and invented only to support a weak cause, because it is defective in proof." 28 It is also a reasonably safe conjecture that the procedure was used no earlier than 1617. W. J. Jones's thorough study, The Elizabethan Court of Chancery, describes the procedural connections between the equity side of Chancery and the courts of common law during the reign of Elizabeth I but does not refer to the feigned issue procedure as such. ${ }^{20}$ An examination of the Huntington Library Ellesmere Manuscripts covering the period 1603-1617 has failed to reveal the use of the feigned issue procedure at that time. ${ }^{30}$ In light of Jones's study and the Elles-

25. 2 Brown's Ch. Rep. 345 (1788).

26. Id.

27. Second Report Made to His MAJesty by the Commissioners appointed to iNquire into the Practice and Procendings of the Superior Courts of Common Law I1 (1830) [hereinafter cited as SECOND REPORT]. See 3 W. BLACKstone, supra note 10 , at $452-53$.

28. Lord Notringham's Manual of Chancery Practice and Prolegomens of ChanCERY AND EQUITY 220 (D. Yale ed. 1965) [hereinafter cited as D. Yale].

29. W. JoNEs, supra note 8 , at $475-81$; see especially $479-81$.

30. Ellesmere began his tenure as Lord Chancellor under Elizabeth $I$ and continued under James I (1603-1617). He was Lord Chancellor during the attacks by Coke upon the powers of the equity courts. It was Ellesmere, in fact, whom Coke sought to have 
mere papers, it appears that references to cooperation between equity and common law courts earlier than 1617 refer to the action at law..$^{31}$ Therefore, it may be inferred that the feigned issue originated during. the approximately 50 year period between the tenures of Francis Bacon (Lord Verulam) and Lord Nottingham as Lord Chancellor of the High Court of Chancery.

There are some indications that the feigned issue procedure may have been initiated during or very shortly after the tenure of Lord Verulam. In Tigh v. Tigh" "a clergyman having died seised in fee of real estate, his heir-at-law brought a suit in the Court of Chancery against the devisee under an alleged will of the deceased to set aside the will on the ground that it was not genuine or that it had been revoked." 33 The devisee had already taken possession of part of the estate and the court ordered that an action at law for trespass be commenced. The issue in the trespass action was ordered to be devisavit vel non that is, to ascertain whether the paper presented was the testator's will. ${ }^{34}$ Both the subject matter of the action, a contested will, and the specific issue, devisavit vel non, were in later years a traditional subject and form of the feigned issue procedure. ${ }^{35}$

Feigned issues were ordered in a variety of situations, particularly when the disputed facts involved questions of the validity of a will, when there was a dispute as to whether one of the parties was the heir at law, and when there was a dispute concerning the existence and size of ancient ecclesiastical tithes. ${ }^{36}$ In the case concerning an heir at

indicted for the ancient crime of Praemenuire on the last day of Hillary Term, February 13,1616 . Ellesmere, however, was gravely ill at the time and died shortly thereafter. There is no evidence, at least at present, to sustain a belief that Ellesmere, at the end of his tenure as Lord Chancellor, instituted the feigned issue in response to this controversy. See Ellesmere Manuscripts 5971, 5972, 5973 (1616) and 2958 (un. dated), Henry E. Huntington Library, San Marino, California.

31. An example of a reference to cooperation at an earlier time can be found in W. LAMBARDE, ARCheion 42 (1957 reprint of 2d ed. 1635) (emphasis in original):

So also I doe not remember, that in our Reports of Common Law there is any frequent mention of Causes usually drawne before the Chancellor, for helpe in

Equitie, but onely from the time of King Henry the fourth . . . .

32. J. Ritchie, Cases Decided BX LORD BAcon, 1617-1621, at 84 (1932). It secms likely that the feigned issue grew in an evolutionary manner from earlier procedures. It is quite similar to the action at law in providing for the trial of legal right and facts incidental to those rights in the common law court. It also has procedural bonds to the activities of the common law side of the High Court of Chancery, known as the Petty Bag. See W. Bohun, supra note 14, at 5 .

33. J. Ritchie, supra note 32 , at 84 .

34. See Black's Law Dictionary 539 (4th ed. 1968).

35. As to the traditional subject matter for the feigned issue of the validity of a will, see $3 \mathrm{~W}$. BLACKstone, supra note 10 , at $452-53$. As to an issue devisatit vel non as a traditional form of the feigned issue, see Bates v. Graves, 2 Ves. Jr. 287, 30 Eng. Rep. 637 (1793); Webb v. Claverden, 2 Atk. 424, 26 Eng. Rep. 656 (1742); Kerrick v. Bransby, 7 Brown Parl. Cas. 437, 3 Eng. Rep. 284 (1727).

36. 3 W. Blackstone, supra note 10 , at $452-53$. 
law, custom and precedent positively required the submission of a feigned issue to a jury. ${ }^{37}$ It was viewed as an abuse of the Lord Chancellor's discretion, however, to order a feigned issue where the court was capable of deciding the use without such a referral. ${ }^{38}$

It is clear that, at least by mid-eighteenth century, the repeated use of the feigned issue had caused the Court of Chancery to establish a standardized formula for the ordering of that procedure. The purpose of the feigned issue was described in a phrase-to "inform the conscience of the Court." ${ }^{30}$ After hearing the arguments the Lord Chancellor would select the appropriate jury to hear the issue and order that a trial proceed at law. ${ }^{40}$ The court then would formulate the issue to be presented before the jury, ${ }^{41}$ declare which parties were to be plaintiffs at law and which defendants at law, ${ }^{42}$ and refer the issue to one of the Masters of the Court "to settle the said issues in case the parties differ about the same ...."43 The final portion of the court's order always reserved "considerations of costs and of all further direc-

37. Dawson v. Chater, 9 Mod. 90, 88 Eng. Rep. 334 (1724).

38. H. BALlow, A TREATISE OF EQuITY 256-58 (1756).

39. G. Goldsmith, supra note 15 , at 367. See also Pemberton v. Pemberton, 11 Ves. Jr. 50, 53, 32 Eng. Rep. 1006 (1805); H. BALlow, supra note 38, at 256-58.

40. For example, in Richards v. Symes, PRO C33/374, part II, at $469 \mathrm{a}-70 \mathrm{~b}$ (1740), the Chancellor ordered "that the plaintiff's bill be retained for 12 months and that the parties do proceed to a trial at law at the next Lent Assizes to be holden for the County of Essex ...." See also Baker v. Hart, PRO C33/385, part II, at 480b$410 \mathrm{~b}$ (1746); Colegrave v. Juson, PRO C33/379, part II, at 721b-22b (1743).

41. For example, the issue formulated by the court in Colegrave v. Juson, PRO C33/379, part II, at 72lb-22b (1743), was:

whether a modus of 40 shillings a year is payable by the owner or occupier of the lands comprised within the manor of Cannhall, otherwise Cannon Hall, lying within the parish of Wanstead in the said county of Essex in lieu of all titles for the same or not....

In Richards v. Symes, PRO C33/379, part II, at 721b-22b (1743), the issue was:

whether George Richards, deceased, did give to the defendant Chilcott Symes the mortgage deed dated the 8th of December, 1717, and the bond from the said defendant to the said George Richards, deceased, of the same date or either and which of them and also whether the said George Richards, deceased, did, at the time of giving the mortgage deed or bond or either of them to the said defendant, declare that he did forgive the said defendant the debt, meaning the debt due by the said bond or mortgage....

The court in Baker v. Hart, PRO C33/385, part II, at $480 \mathrm{~b}-410 \mathrm{~b}$ (1746), stated that the isste was:

whether Frances Diana, late wife of the said Richard Hart and mother of the said defendant Francis Hosier Hart the infant, was daughter and heir of Francis Hosier Esq., deceased. Secondly, if she was not then whether William Baker, deceased, the father of the plaintiffs was heir of the said Francis Hosier ....

42. In Richards v. Symes, PRO C $33 / 374$, part II, at 469a-70b (1740), the Court made the defendant in equity the plaintiff in the court of law. The defendant in equity, who possessed an uncancelled mortgage instrument and the deeds which secured them, claimed that the plaintiff's father, to whom the deeds had been assigned, had forgiven them. Requiring the defendant in equity to prove the cancellation of the instruments would seem to have been a more equitable allocation of the burden of proof and may even have been an indication that there was a rebuttable presumption that an un. cancelled debt was valid, even if in the debtor's possession.

43. See, e.g., Baker v. Hart, PRO C33/385, part II, at $480 \mathrm{~b}-410 \mathrm{~b}(1746)$. 
tions until after the said trial shall be had when any of the parties are to be at liberty to apply to the Court as there shall be occasions." 44

Later it was said that the Chancellor was not bound by the feigned issue jury verdict and that he could accept the verdict or send the issue back to the court of common law for retrial. ${ }^{4 \tilde{5}}$ With one possible exception, ${ }^{46}$ however, the source materials did not disclose any cases in which the Chancellor, after ordering a feigned issue sent to the common law courts, rejected the jury verdict and decided the case on his own.

Apparently, the decision to reject a verdict, except in the most unusual circumstances, was regarded as beyond the scope of the Lord Chancellor's powers. At the same time, any motion or order for a new trial of a feigned issue-whether on grounds of error caused by the court of law or of dissatisfaction with the verdict-could be made only before and ordered only by the Lord Chancellor of the Court of Chancery. In this respect, therefore, the feigned issue procedure differed from the referral through an action at law in which motions for a new trial had to be made in the court of law where the trial had taken place.47

In judgments on motions for retrial in a feigned issue case, the weight accorded the verdict by the Chancellor was somewhat less than it would have had in an autonomous common law action. In Stace v. Mabbot, ${ }^{48}$ Chancellor Hardwicke addressed himself to the different treatment of motions for retrial in the common law courts and the Court of Chancery. In a trial in a common law court, if the verdict was "given on evidence fairly according to proper notice, and the judge does not report that he is dissatisfied with it, or that it was against evidence," 40 the court was required to deny the motion for retrial. Chancery, however, was concerned only with satisfying the conscience of the court

44. Id.

45. See Hampson v. Hampson, 3 Ves. \& Bea. 41, 35 Eng. Rep. 395 (1804).

46. Lord Chancellor Hardwicke, in Stace v. Mabbot, 2 Ves. Sr. 552, 554, 28 Eng. Rep. 352, 353 (1754), described a

case in Lord King's time relating to a rent-charge, granted out of the estate of Mr. Hockmore in Devonshire. It had been twice or thrice tried at common law, tried upon distress taken on the rent-charge and an avowry, and where the question was singly, whether it was a forgery or not, and upon all those trials verdict was found for the deed. A bill was notwithstanding brought here to set it aside for forgery; and Lord King sent it to trial under an issue directed by the court; and I believe, there was a new trial after that: and notwithstanding all those verdicts Lord King made a decree to have it brought into court and cancelled here, the former trials not being to the satisfaction of the court.

While the concluding portion of Lord Hardwicke's description could be taken as suggesting the possibility of rejecting outright the feigned issue verdict, it appears to be exceptional.

47. See p. 1003 \& note 19 supra.

48. 2 Ves. Sr. 552, 554, 28 Eng. Rep. 352, 353 (1754).

49. Id. at 553, 28 Eng. Rep. at 353. 
concerning disputed facts. This being so, "if . . . upon any material and weighty reason the verdict is not such as to satisfy the court to found a decree upon, there are several cases, in which this court has directed a new trial for further satisfaction, notwithstanding it would not be granted, if in a court of common law ....".50

There seems to have been a practice that an heir at law would not have his rights terminated without the ordering of a feigned issue. It also appears to have been at least a tacit rule that, in the case of an inheritance, no less than one retrial was required "if any sort of objection [arose] to the trial, and that notwithstanding the objection of inconvenience in examining over and over, which objection [had] not prevailed. This extend[ed] also to a personal demand, where of considerable value, and where the court [was] not satisfied with the grounds on which the determination was made at law ...." ${ }^{51}$ The satisfaction-of-conscience formula to the review of feigned issue cases in several instances resulted in as many as three or four retrials before the courts of common law. ${ }^{52}$

Perhaps it was the frustration of having to order repeated retrials to obtain a verdict consistent with overwhelming evidence that ultimately led the Court of Chancery to assert its authority to determine fact issues without the benefit of a jury verdict. ${ }^{53}$ Nottingham in the seventeenth century had decried "the multiplying of trials in feigned actions upon feigned issues ...." 54 By 1790 Thurlow was moved to express concern with the proliferation of procedural chicanery in the use of the feigned issue, such as withholding of evidence in the first trial with the object of enhancing chances of victory in the second. In Standen $v$. Edwards ${ }^{55}$ he pronounced a remedy for such fraudulent activities-retrials in feigned issue cases would be granted only on the basis of evidence that could not have been presented earlier.

Soon after the beginning of the nineteenth century the Chancellor

50. Id. at 553-54, 28 Eng. Rep. at 353. One of the circumstances in which Chancery but not the common courts would grant a new trial was when there was newly discovered evidence. It is interesting to speculate whether the Chancery practice concerning new trials in feigned issue cases may have eventually influenced the common law courts' attitude in the direction of liberalization; cf. FED. R. Crv. P. 60(b).

51. Stace v. Mabbot, 2 Ves. Sr. 552, 554, 28 Eng. Rep. 352, 353 (1754).

52. See, e.g., Pemberton v. Pemberton, 13 Ves. Jr. 290, 33 Eng. Rep. 303 (1805).

53. If this speculation is correct, it is exactly paralleled by the evolution a century later in the United States federal courts of the motion for judgment n.o.v. as a device replacing a retrial with directed verdict to expunge jury verdicts that were unsupported by substantial evidence. See the sequence in Slocum v. New York Life Ins. Co., 228 U.S. 364 (1913); Baltimore \& Caroline Line v. Redman, 295 U.S. 654 (1935); FED. R. Civ. P. 50(b); and Montgomery Ward \&. Co. v. Duncan, 311 U.S. 243 (1940). See also

F. JAMES, CiviL Procedure $\$ 7.22$, at 331-36 (1965).

54. D. Yale, supra note 28 , at 220.

55. 1 Ves. Jr. 133, 135-36, 30 Eng. Rep. 266, 267 (1790). 
distinctly asserted his authority to determine facts. Mere procedural errors, such as the failure to allow a paper to be introduced as evidence in a common law court, were not sufficient to require a retrial. ${ }^{.6}$ The Chancellor was concerned with the suit as a whole and not with individual procedural irregularities. Although some evidence may have been improperly rejected at law, if he were satisfied that on the whole justice had been done, the Chancellor could refuse a new trial..$^{57}$

As the nineteenth century progressed, resistance to the feigned issue increased outside the Court of Chancery. In 1816, Chief Baron Richards of the Exchequer Court said that "he would always oppose sending issues to a jury where it could possibly be avoided, unless it were in the well-known excepted cases of a rector and heir-at-law." 58 In 1830, the commissioners appointed to inquire into the practice and proceedings of the courts of common law expressed objection to the wager form of the feigned issue and the use of the fictitious discourse between the parties. ${ }^{59}$

The wager form of the feigned issue was finally eliminated by the Gaming $\mathrm{Act}^{\mathrm{BO}}$ in 1845. Thereafter, the courts continued to use the essential features of the feigned issue procedure in simplified form. The procedure was initiated when the court of equity directed the party it had designated plaintiff to sue out a writ of summons against the party the court had designated defendant. ${ }^{01}$ Thus, by this time the use of the jury was wholly discretionary.

\section{The Feigned Issue in American Procedure}

There has not been sufficient evidence uncovered to determine when the feigned issue procedure was received in the procedure of the American colonies and states. ${ }^{62}$ It is clear, however, that the procedure was used recurrently in a number of American jurisdictions from the

56. Hampson v. Hampson, 3 Ves. \& Bea. 41, 35 Eng. Rep. 395 (1804).

57. See Pemberton v. Pemberton, 11 Ves. Jr. 50, 52-53, 32 Eng. Rep. 1006, 1007 (1805).

58. Mytton v. Harris, 3 Price Exch. Rep. 19, 25 (1816). This characterization of earlier instances of an established practice as "exceptions" to a newly announced rule reformulation is, of course, familiar judicial legerdemain.

59. The SECOND REPORT, supra note 27 , at 11, stated:

It has often been lamented that the Courts of Law should be obliged to entertain any suits founded upon wagers. But whether suits of this description ought or ought not to be absolutely prohibited, we certainly think it very unfit that they should receive any countenance from the forms of proceeding employed for bringing to trial questions judicially proposed. We also disapprove of the fictitious nature of the issues in question.

60. The Gaming Act, $8 \& 9$ Victoria, c. 109, $\$ 19$ (1845).

61. WhaRTon's Law LeXICon 409 (14th ed. 1938).

62. It is not clear that the wager form of the feigned issue, prevalent in England until the 1840's, was ever used in the American court systems. 
last decade of the eighteenth century until the twentieth century. ${ }^{63}$ Those American jurisdictions, such as New Jersey and New York, that maintained the classic English separation of equity and law court systems imported the feigned issue in essentially its original form. On the other hand, those American courts that blended equity and legal procedure, in one fashion or another, tended to deformalize the feigned issue procedure. Equity procedure in the federal courts illustrates this latter tendency.

In both cases the doctrine governing referral of fact issues from equity to law for jury trial continued to develop. The American doctrine began at the point the English rule had reached as of 1790-1800; referral of fact issues for jury trial ordinarily took place in cases of inheritance or title or when there was substantially conflicting evidence. The evolution of the doctrine moved in the direction of discretionary authority of the Chancellor to order a jury trial. ${ }^{64}$ The transformation was complete by the beginning of the twentieth century, when it was held that referral to a jury was wholly discretionary and the jury verdict merely advisory ${ }^{65}$ This development is most easily presented by examining the reported cases in several American jurisdictions-New Jersey, New York, Virginia, and the federal system. ${ }^{66}$

\section{A. New Jersey}

Of all American jurisdictions, New Jersey used the feigned issue procedure in a way that most closely followed its English antecedent. New Jersey maintained the classic separation of equity and law. A statute of 1799 permitted the same procedural bonds between the equity courts and the courts of law as existed under the English feigned issue format-the Court of Chancery was authorized to direct fact issues to trial in the state supreme court. ${ }^{67}$

As in England, when a New Jersey Chancellor was confronted with

63. $30 \mathrm{~A}$ C.J.S. Equity $\$ 495$ (1965) indicates that some form of the feigned issuc procedure was used in 27 American jurisdictions and by a number of federal courts.

64. See Van Alst v. Hunter, 5 Johns. Ch. 148 (N.Y. 1821); Miller v. Wack, 1 N.J. Eq. (1 Saxton) 204 (183I); Trenton Banking Co. v. Woodruff, 2 N.J. Eq. (1 H.W. Green) 117 (1838).

65. Cf. FED. R. Civ. P. 38(a) and 39(c).

66. A number of other jurisdictions generally followed the feigned issue model. Tennessee's feigned issue was authorized by statute, 1782 , c. 11 , and 1801 , c. 6, as discussed in Simmons v. Tillery, 1 Overton 274, 282-83 (Tenn. 1808). Georgia had no such statutory authorization; its feigned issue procedure was a product of common law tradition and practice. See McGowan v. Jones, R. M. Charlt. Super. Ct. Rep. 184 (Ga. 1822). For the Maryland feigned issue procedure, see Fornshill v. Murray, I Bland 479 (Md. 1828). For the Kentucky feigned issue procedure, see Ayres v. Scott, Adm'n of Sneed, $2 \mathrm{Ky}$. (Sneed) 162 (1802).

67. REvised Laws of NEw Jersey, 1820 (Laws in Force 1703-1820), § 38, at 494. 
a disputed fact situation, he could resolve the matter by ordering either a feigned issue or an action at law. Indeed, it may have been the practice in New Jersey for the Chancellor to seek the advice of the courts of law concerning the respective merits of trying a given case by one of the two procedures. In Decker $v$. Caskey, ${ }^{68}$ the Chancellor called upon the Chief Justice of the Supreme Court of New Jersey for such an opinion in a question of law and fact surrounding the validity of a deed. The Chief Justice recommended that the Chancellor order an action at law in ejectment to be tried in the Supreme Court, rather than a feigned issue.

By the 1830's the New Jersey Chancellor apparently considered it appropriate to order a feigned issue only when an especially difficult dispute over a question of fact arose. The equity courts, which appear to have been hearing live testimony at this time, were said to direct a feigned issue only "in cases of real difficulty, growing out of contradictory testimony; or opposing facts and circumstances, which it is impossible for the court to reconcile." 69

In Bassett v. Johnson ${ }^{70}$ the feigned issue was used in such a case. Plaintiffs had sought a permanent injunction against the construction of a dam on the grounds that it was causing flooding damage to their lands. Witnesses testified for both parties, presenting the court with contradictory evidence on the extent of and cause of damage to the plaintiffs' lands. Unable to determine for itself which set of facts was correct, the court chose to rely upon a jury determination, stating that "in important cases, where the evidence of respectable witnesses, with the same means of information, is contradictory, so as to raise serious doubts on the mind of the court, it is proper to direct an issue, or order a suit at law." 71 It is clear from Trenton Banking Co. v. Woodruff ${ }^{72}$ that the referral procedure was regarded as discretionary. In this case, the Chancellor observed that the feigned issue was "recognized in all the books, and is expressly authorized by our statute," but that "nothing but imperious necessity would induce me to take this course . . .."73

The form of the New Jersey equity court's order directing a feigned

68. I N.J. Eq. (I Saxton) 427 (1831).

69. Miller v. Wack, 1 N.J. Eq. (I Saxton) 204, 215 (1834). The court, after viewing the entire case, decided that the disputed fact-whether a mortgage had been cancelled with the consent of the mortgagees-could be decided without the assistance of a feigned issue.

70. 3 N.J. Eq. (2 H.W. Green) 417 (1836).

71. Id. at $42 \mathrm{l}$.

72. 2 N.J. Eq. (1 H.W. Green) 117 (1838).

73. Id. at 132 . 
issue follows, almost exactly, the form used by the English High Court of Chancery. The court ordered a feigned issue, designated the court and manner of trial, prescribed the role each participant was to assume, delineated the issue to be determined, stipulated the evidence which was to be produced before the court of law, and provided for the equity reserved. ${ }^{74}$ When the feigned issue was returned to the New Jersey court of equity and questions of retrial were raised, the court handled such issues much as the English High Court of Chancery had handled them in Stace v. Mabbot ${ }^{75}$ and Hampson $v$. Hampson. ${ }^{76}$

\section{B. New York}

The tenor of discussion in the first reference to the feigned issue procedure uncovered in the New York reports, suggests the requirement of a referral when the evidence is in conflict. ${ }^{77}$ Later New York

74. The great similarity to the form of English decrees is evident in the order in Bassett v. Johnson, 2 N.J. Eq. (I H.W. Green) 154, 155-56 (1839):

It is ordered, adjudged and decreed, and the chancellor by virtue of the power and authority of this court doth order, adjudge and decree, at the instance and upon the motion of the complainants by their said counsel, that a feigned issue be formed in the supreme court of judicature of New Jersey, and tried in the ordinary manner, between the said Joseph Bassett, Thomas Sinnickson and John Sinnickson as plaintiffs, and Isaac Johnson and William Johnson as defendants, by a jury of the county of Salem, at the next circuit court to be holden in that county, to inquire, ascertain and determine, by the verdict of said jury, whether the erection of the dam by the defendants, mentioned in the pleadings of this cause, has seriously and permanently affected and injured the meadows of the complainant lying above it; and that either party may notice the cause for trial; and the defendants in the issue may carry down the record by proviso, in order that the trial may be had at the ensuing circuit; and that a special jury will be ordered by this court on the application of either party, subject to the preference given to the plaintiffs by the rules of the supreme court; and that copies of the depositions, certified by the clerk of this court, be read and received in evidence on said trial as rebutting evidence or as original evidence, in case the witnesses who testified to the same be dead, or from sickness or other sufficient cause be unable to attend said trial; and that no new witnesses shall be produced at said trial, without giving ten days notice of the intention, with the name, addition and place of abode of such witness; and that all further directions be reserved until the said issue shall be tried, and the postea returned to this court.

Compare this order with the order in Parsons v. Parsons, PRO C33/495, at 71la-11b (1796), at note 11 supra.

75. 2 Ves. Sr. 552, 28 Eng. Rep. 352 (1754).

76. 3 Ves. \& Bea. 41,35 Eng. Rep. 395 (1814).

77. In LeGuen v. Gouverneur, I Johns. 436, 500 (N.Y. 1800), the court said:

It ought regularly to proceed from the chancellor himself, to inform his own conscience, where the evidence is insufficient for that purpose; and even with respect to him, it is not a power to be exercised at pleasure, and depending on arbitrary discretion. In a government of laws, no such discretion can exist . . .

It seems evident that there is a vestige here of the medieval idea of a jury verdict's being evidence. An especially interesting use of the feigned issue appears in John Doe v. Richard Roe, I Cow. 216 (N.Y. 1823) (motion for a new trial in a feigned issue determination of whether, in a divorce proceeding, one of the parties was guilty of adultery); compare the reference to the feigned issue procedure in Den $v$. Fen, I Caines 486 (N.Y. 1803). See also the reference to LeGuen v. Gouverneur in $2 \mathrm{~J}$. Goebel, Law Practice of Alexander Hamilton 78-79 (1969). 
equity court decisions seem to indicate that, after 1800 , caution in the exercise of the court's discretion developed into a reluctance to order the feigned issue and a reliance on the competence of the equity court to decide disputed fact. The case of Van Alst $v$. Hunter, ${ }^{78}$ in 1821 , is an early indication of that attitude. While the court was principally concerned with the propriety of retrial of a feigned issue, it broke the long-standing English requirement that inheritance cases required at least one retrial before determining the rights of the heir. The court, noting that the more usual course in the English Chancery was to grant a second trial, concluded that this was not always the case and that there were precedents both ways. ${ }^{79}$

By 1833 , in the case of Idley $v$. Bowen, ${ }^{80}$ even the preference for referral had been abandoned. The Court of Errors, hearing an appeal from a chancery order directing an issue devisavit vel non, stated that "it is competent for a court of equity, however, even where the evidence is contradictory and nearly balanced, to decide for itself without invoking the aid of a jury." 81

\section{G. Virginia}

The Virginia cases show an even earlier assertion of the Chancellor's ability to make factual determinations on his own. Although the Virginia courts sitting in equity made use of the traditional feigned issue formulas, such as returning issues for retrial as many as three times, ${ }^{82}$ as early as 1794 they had declared their independence from the jury. In Southall $v$. M'Keand, ${ }^{83}$ the Chancellor had ordered a feigned issue to determine certain boundaries of the property in question. The first jury was unable to decide the question; the second jury found for the defendants, but the trial judge certified to the Chancellor that the weight of the evidence favored the plaintiff. The

78. 5 Johns. 148 (N.Y. 1821).

79. Id. at 154. The court relied upon the English case of White v. Wilson, 13 Ves. Jr. 87, 33 Eng. Rep. 227 (1806), an atypical case where the heir, against whom the verdict had gone, failed to lay any grounds for his request for a new trial. Under such circumstances, the court rejected the heir's request for a retrial.

80. 11 Wend. 227 (N.Y. 1833).

81. Id. at 234. The court cited 2 Atkyns 295, 2 Vesey 256, and Barnadiston's Chancery Reports 100 in support of this view. Unfortunately, the first two citations appear to be incorrect and the third, Chamberlayn v. Symonds, is not supportive of the statement reported.

New York equity courts did follow the English rule that no retrial was necessary where the new evidence would not have changed the verdict. See Mulock v. Mulock, I Edw. 14, 18 (N.Y. 1831); Anthorp v. Comstock, 2 Paige 481, 487-88 (N.Y. 1831); cf. Patterson v. Ackerson, 1 Edw. 96, $101-02$ (N.Y. 1831).

82. See Stannard v. Graves, 2 Call. 369 (Va. 1800).

83. 1 Wash. 336 (Va. 1794). 
Chancellor ignored the certification and took the verdict sufficient to "satisfy his conscience" as to the facts in dispute. The appellate court, although recognizing that the decision was within the Chancellor's discretion, ruled that he should not "depart from the general rule" by accepting a verdict that was, in the trial judge's estimate, against the weight of the evidence. ${ }^{84}$ Thereafter the course of doctrinal evolution in Virginia moved toward excluding the use of the jury. Although the Virginia courts of equity continued to recite the classic formula that they had "discretion to inform the conscience of the court," 85 the exercise of discretion was narrowly controlled through appellate review. Moreover, it was controlled in the direction of refusing referral, as indicated in Beverly $v$. Walden, ${ }^{86}$ decided in 1870 in which the court stated that "until the case [is] rendered doubtful by the conflicting evidence of the opposing parties, the defendant cannot be deprived by an order for an issue, of his right to a decision by the court on the case as made by the pleadings and proofs." ${ }^{87}$

\section{Federal Courts}

The earliest reported opinion involving the use of the feigned issue in the federal courts appears to be Field $v$. Holland, ${ }^{88}$ decided in 1810. The matter in question was whether a series of payments from an obligor to an obligee were to be applied to a judgment debt, thereby rendering invalid an execution of the judgment, or to other debts between the parties. Since the evidence was confused and conflicting, the trial judge ordered the question resolved by referral to a jury trial. In commenting on this, Chief Justice Marshall indicated that the court could properly refer the issue but was not required to do so in the circumstances presented: 89

It was completely in the discretion of the court to ascertain this fact themselves, if the testimony enabled them to ascertain it; or, if it did not, to refer the question either to a jury, or to auditors. There was, consequently, no error, either in directing this issue, or in discharging it.

The significance of this passage is difficult to gauge. The statement that the court could "ascertain this fact themselves" suggests that the

84. Id. at 337 .

85. Hord's Adm'r v. Colbert, 28 Grat. 49, 60 (Va. 1877).

86. 20 Grat. 147 (Va. 1870).

87. Id. at 154. The judgment of the lower court was reversed and the case dismissed.

88. 10 U.S. (6 Cranch) 8 (1810).

89. Id. at 22 . 
judge sitting in equity was authorized to determine the facts if he wished. At the same time, there is also the suggestion that if the testimony did not "enable" the court to "ascertain" the fact, then it should go to a jury or to auditors. This suggestion implies that a jury trial was preferred and perhaps necessary where the evidence was in serious conflict. The ambivalence toward jury trial substantially corresponds to that exhibited in the English cases of about the same time. ${ }^{00}$

The relationship between jury trial and equity jurisdiction in the federal courts was not directly addressed by the Supreme Court until two decades later, in Parsons $v$. Bedford, ${ }^{91}$ decided in 1830 . There, the question of jury trial was obliquely involved in a case in which the primary issue was the mode of appellate review to be used in a proceeding commenced in the state courts of Louisiana and subsequently removed to the federal district court in that state. ${ }^{92}$ In the course of his opinion for the majority, Justice Story said:

The constitution had declared, in the third article, "that the judicial power shall extend to all cases in law and equity arising under this constitution ... ." and to all cases of admiralty and maritime jurisdiction. It is well known, that in civil causes, in courts of equity and admiralty, juries do not intervene, and that courts of equity use the trial by jury only in extraordinary cases to inform the conscience of the court. When, therefore, we find that the amendment requires that the right of trial by jury shall be preserved in suits at common law, the natural conclusion is, that this distinction was present to the minds of the framers of the amendment. ${ }^{93}$

90. It seems likely that the evolution of the scope of jury trial in federal courts may have been part of the controversy between the Federalist bench and the Republican administration and Congress of which Marbury v. Madison, 5 U.S. (1 Cranch) 137 (1803), is a more famous aspect. But see Tachau, The Federal Courts in Kentucky, 1789-1816 (unpublished Ph.D. Thesis, University of Kentucky Library, 1972). It is possible that the assumption by federal judges sitting in equity to decide fact issues themselves, or to use a jury as merely an advisory body, was influenced not only by the contemporary change in English practice but also by the circumstance that they heard and decided such issues without a jury when sitting in admiralty.

It may be noted that in Parsons v. Bedford, 30 U.S. (3 Pet.) 433 (1830), Justice Story assimilated admiralty and equity as courts of "civil causes." See text accompanying note 93 infra. This seems to have been a considerable oversimplification of the doctrinal, procedural, and political relationships between chancery and admiralty. See also Waring v. Clarke, 46 U.S. (5 How.) 441 (1847).

91. 28 U.S. (3 Pet.) 433 (1830).

92. Professor James has observed that the question of jury trial right often has been implicitly involved in cases with a different principal issue: "To put it colloquially, jury trial (or court trial) was often merely the tail of the dog under a system where you had to take the whole dog." F. JAMEs, supra note 53, at 345 . We are inclined to think that the choice of dog, so to speak, was always strongly influenced by whether the jury trial tail came with it.

93. 28 U.S. (3 Pet.) at 446.47 (emphasis in original). Story went on to say:

And Congress seems to have acted with reference to this exposition in the ju-

diciary act of 1789 , ch. 20 (which was contemporaneous with the proposal of this 
Justice McLean in his dissenting opinion disagreed as to whether the proceeding in issue was a "suit at common law," but agreed that the question of jury trial depended on whether the proceedings should be so regarded. ${ }^{94}$

Subsequent federal cases established that use of the jury was discretionary, perhaps even a matter of simple and unreviewable preference of the individual judge. In Ely $v$. Monson \& $B$. Manufacturing Co., a patent case, the Circuit Court for the District of Massachusetts recognized the existence of the feigned issue, but rejected its use in that district. ${ }^{95}$ The Circuit Court for the District of Rhode Island, on the other hand, sanctioned the use of the feigned issue in another patent case, Goodyear $v$. Providence Rubber Co. ${ }^{96}$

Another feature of the federal court use of the feigned issue was the change in the spirit of the federal judges' decisions on motions retrial. Whereas English Chancellors would send issues back to courts of law as many as four times, federal judges could and did resolve equity matters by rejecting the facts determined by the jury hearing the feigned issue. The Supreme Court in Johnson $v$. Harmon, ${ }^{97}$ in 1876, and 13 years later in Idaho \& Oregon Land Improvement Co. v. Bradbury ${ }^{98}$ discussed this expedited decision process: The court was not bound to submit any issue of fact to the jury, and if it did so, it could disregard the findings of this jury or accord them weight in the final decree according to the court's own view of the evidence.

Federal courts have continued to use the feigned issue procedure

amendment); for in the ninth section it is provided, that "the trial of issues in fact in the district courts in all causes, except civil causes of admiralty and maritime jurisdiction, shall be by jury;" and in the twelfth section it is provided, that "the trial of issues in fact in the circuit courts shall in all suits except those of equity, and of admiralty and maritime jurisdiction, be by jury" ... .

Id. at 447 (emphasis in original).

This line of analysis of course suggests the conclusion that the demarcation between jury trial and nonjury trial corresponds to that between law and equity. It would be equally appropriate to conclude, merely as a matter of textual analysis of the Amendment and the Judiciary Act, that these provisions were aimed at assuring jury trial not merely in cases at law but in all nonadmiralty civil causes, i.e., in equity suits as well as in suits at common law.

94. He stated:

The words in the latter clause of the seventh article "and no fact tried by a jury shall be otherwise re-examined in any court of the United States," refer to the first clause of the sentence, which limits the trial to "suits at common law." If this were not the true construction of the sentence, facts found by a jury in an issue directed by a court of chancery, would be conclusive on the chancellor. The verdict has never been so considered, and especially in the appellate courts of chancery.

28 U.S. (3 Pet.) at 455.

95. 8 F. Cas. 604 (No. 4431 ) (C.C.D. Mass. 1860).

96. 10 F. Cas. 712 (No. 5583) (C.C.D.R.I. 1864).

97. 94 U.S. 37I, 372 (1876).

98. 132 U.S. 509, 515-16 (1889). 
in the twentieth century. By this time, however, the trend that began in the handling of questions of retrial had culminated in the total detachment of the form of the procedure from an understanding of its historical substance. The use of the feigned issue became an exercise in the rote application of the discretionary powers possessed by a resourceful Chancellor: "Indeed, the issue so submitted to a jury called in an equity case is called a 'feigned issue,' because of its purely advisory character .... The Chancellor may call a jury or may refer the matter to a master or hear it himself." 99

Recent history has seen the full running of the doctrinal cycle. Its last phase is set out in this example of the "modern" doctrine:

We base our decision to award a jury trial in this case on our discretion as a Court of equity to submit any questions of fact to a jury. There is no principle of law, nor any constitutional guarantee, which requires us to try an issue without a jury. We base the exercise of our discretion in this matter on our belief that the questions of fact to be determined in the separate trial are best answered by a jury. In other words, answering them may involve the resolving of conflicting testimony. ${ }^{100}$

\section{Reflections on the Evidence Presented: Speculative Inquiry}

The evidence we have reviewed invites two sets of speculative inferences. The first concerns the relationship between courts of equity and common law in England before 1791 with reference to fact determinations in contested equity cases. The second concerns the relation between the practice in this regard in England before 1791 and the American practice, particularly in the federal courts after 1791.

As to the first, the data examined concerning the English feigned issue procedure suggest a reevaluation of the traditional view of the Lord Chancellor's powers. The authors hypothesize that the office of the Lord Chancellor was not originally endowed with the power to decide questions of fact, though it assumed that power by the nineteenth century. Given the comparative strengths of the Chancellor's discretion in the case stated, the action at law, and in the feigned issue, there may have been three more or less distinct stages in the development of the powers of the Lord Chancellor.

The first stage might be delineated by emphasizing the discovery powers of the equity side of Chancery-the Lord Chancellor was in-

99. Nashville Ry. \& Light Co. v. Bunn, 168 F. 862. 864 (6th Cir. 1909).

100. Taxin v. Food Fair Stores, Inc., 24 F.R.D. 457, 460 (E.D. Pa. 1959). 
vested with the procedural powers for ordering and supervising examinations, sending commissions into the country, and generally controlling the collections of records and written testimony in legal controversies. Certainly the Chancellor must have been empowered to determine a controversy when the evidence was one-sided, but may have been obliged to send difficult disputes to the common law courts.

Control over the procedures for transfer to the common law courts in the case stated and the action at law would represent the second stage. The Lord Chancellor, under these procedures, could formulate the matters to be determined by the common law courts, but the latter remained the seat of the power to decide disputed questions of fact and legal rights. Here, the determination of a controversy was returned to Chancery for a pro forma pronouncement by the Lord Chancellor on the equity reserved.

In the third phase, marked by the use of the feigned issue, the Lord Chancellor controlled all aspects of a controversy in equitythe discovery process, the decision of legal questions, and the formulation of fact issues-and used the common law jury as a decisional body, relying upon the jury to satisfy the conscience of the court. Ultimately, the Chancellor decided the fact issues himself, aided if he saw fit by a jury that was merely advisory. As of 1791, however, this power had not yet been clearly established.

The second line of analysis concerns the relationship between the practice of jury fact-determination in England and the constitutional position of the jury in America. The hypothesis that juries determined fact issues in English equity before 1791 raises several questions of constitutional history. One significant issue is whether the struggle over jury trial in the American colonies was more distinctly a struggle between royal government and local autonomy than has been supposed. If it is assumed that courts of equity in England determined fact issues, attempts by the English government to invest the governorin-council with plenary jurisdiction, including jurisdiction to determine fact, as against colonial common law courts with juries, was simply an attempt to implant in the colonies the practice model of the home country. If it is assumed, on the contrary, that the equity courts in England referred fact issues to juries, investing the governorin-council with jurisdiction that included the power to find facts represented a much more aggressive measure. ${ }^{101}$ 
Apart from the historical questions there are contemporarily significant implications. If jury trial was the normal mode of resolving controverted issues arising in Chancery cases, the significance of the Seventh Amendment provision for jury trial in "suits at common law" may be different than has commonly been assumed. Hypotheses in this respect are difficult to formulate, because our own research has been only exploratory and because other research on the issue is fragmentary. Moreover, the research that has been done to date seems to have proceeded on the assumption that under English practice the courts of equity decided fact questions arising before them. On this assumption the historical boundary between actions at law and suits in equity is also the historical boundary between issues tried by jury and issues tried to the court. If this assumption is not made, however, the situation looks quite different, and much more complicated.

If one assumes that juries were employed to determine issues of fact in equity cases up until about 1791, then it can be argued that the jury trial guarantee in the Seventh Amendment applies to all situations where a common law jury was employed, including those in which it was used to determine facts for the Chancellor in suits set up through the feigned issue. On this analysis federal trial courts sitting in equity would be obliged to use juries to resolve disputed fact questions. This is substantially the result implied by Beacon Theatres, Inc. $v$. Westover. ${ }^{102}$ This case, while being completely ahistorical in terms of nineteenth and twentieth century doctrine and practice, ${ }^{103}$ would paradoxically represent a restoration of jury trial to the position it apparently had in England at the time the Seventh Amendment was adopted. The implications of such a conclusion are far-reaching, since they would cast serious doubt on the power of Congress to prescribe nonjury trial in noncommon law actions as it has done, for example, in the Federal Tort Claims Act. ${ }^{104}$

This is not the only possible analysis, however, and perhaps not the soundest one. It is also possible to read the Seventh Amendment as a compromise of the jury trial question, worked out in a context in which it was recognized that juries were used in equity. The compromise was, simply, that there was a guarantee of jury trial in "suits at common law" but the question of the use of juries in equity was left open. This inference is supported by the fact that some of the

102. 359 U.S. 500 (1959).

103. See Note, Right to Jury Trial in Cases Involving Both Equitable and Legal Issues, 47 CALIF. L. REV. 760 (1959).

104. 28 U.S.C. $\$ 2402(1970)$. 
proposals for the Bill of Rights concerning jury trial would have guaranteed jury trial in "civil actions" (which would include both common law actions and suits in equity), whereas the guarantee as adopted refers only to the more limited category denoted by "suits at common law." 105 On this view, the decision in Parsons v. Bedford ${ }^{106}$ in 1830 is not a mere restatement that the Seventh Amendment applies only to actions on the common law side of the court but a positive exercise of judicial lawmaking to that effect.

Such an interpretation of Parsons v. Bedford means that the question of jury trial, except in "suits at common law," was treated as a matter for nonconstitutional lawmaking. After 1791, that question was resolved by judicial practice in favor of nonjury trial, except that the trial court in its discretion might impanel a jury for an advisory verdict. ${ }^{107}$ On that basis, however, it is equally legitimate for the question to be resolved by judicial decision in favor of jury trial, as in Beacon Theatres. ${ }^{108}$ Moreover, and of greater contemporary significance, it is legitimate for Congress to prescribe the mode of trial in actions other than "suits at common law" in the narrowest sense, that is, suits to enforce rights created by Congress that are something more than simple analogues of rights of action available at common law. ${ }^{100}$

The evidence we have presented is too meager to permit any wellfounded choice between these analyses. It is sufficient, however, to indicate that the mandate of the Seventh Amendment is both more complex and perhaps more uncertain than has traditionally been supposed. If, as of 1791, the English Court of Chancery and the American state courts administering equity were not independent of the jury in making determinations of disputed fact issues, the subsequent status in this regard may yet be subject to the "felt need of the masses."

105. See the sources cited in P. Bator, P. Mishkin, D. Shapiro \& H. Wechsler, Hart \& Wechsler's The Federal Courts and the Federal System 21-22 (2d ed. 1973); Henderson, The Background of the Seventh Amendment, 80 HARv. L. REv. 289 (1966). 106. 28 U.S. (3 Pet.) 433 (1830); see pp. 1016-17 supra.

107. Cf. Tachau, supra note 90 , at 293-98.

108. 359 U.S. 500 (1959). See also Ross v. Bernhard, 396 U.S. 531 (1970). It follows that the idea of a constitutional right to a nonjury trial is difficult to support: $c f$. Note, The Right to a Non-jury Trial, 74 Harv. L. REv. 1176 (1961). See also Fitzgerald v. United States Lines Co., 374 U.S. 16 (1963).

109. See Note, Congressional Provision for Nonjury Trial under the Seventh Amend. ment, 83 Yale L.J. 401 (1973). But see Curtis v. Loether, 42 U.S.L.W. 4259 (Feb. 20, 1974). 